\title{
Soilborne Oospores of Phytophthora infestans in Central Mexico Survive Winter Fallow and Infect Potato Plants in the Field
}

\author{
S. P. Fernández-Pavía, Instituto de Investigaciones Agropecuarias y Forestales, Universidad Michoacana de San \\ Nicolás de Hidalgo, Morelia, Mexico 58240; N. J. Grünwald, United States Department of Agriculture- \\ Agricultural Research Service, Prosser, WA 99350; M. Díaz-Valasis and M. Cadena-Hinojosa, Campo \\ Experimental Valle de Mexico, CIR-CENTRO INIFAP, Chapingo, Mexico 56230; and W. E. Fry, Department of \\ Plant Pathology, Cornell University, Ithaca, NY 14853
}

\begin{abstract}
Fernández-Pavía, S. P., Grünwald, N. J., Díaz-Valasis, M., Cadena-Hinojosa, M., and Fry, W. E. 2004. Soilborne oospores of Phytophthora infestans in central Mexico survive winter fallow and infect potato plants in the field. Plant Dis. 88:29-33.

Survival and infectivity of oospores in soils naturally infested with $P$. infestans oospores were studied in central Mexico. Sporangia were selectively eliminated from soil samples to determine infectivity attributable to the presence of oospores. Selective elimination of sporangia was achieved by two cycles of wetting and drying the soil. Oospore concentration, viability, and infectivity varied among soils collected during the winter fallow in different locations of central Mexico. In some soils, oospores were infective regardless of the time at which they were collected during the winter fallow. However, oospore viability and infectivity decreased following 2 years of intercropping. The number of stem lesions and initial disease severity were significantly higher in soils with moderate (20 to 39 oospores $\mathrm{g}^{-1}$ soil) oospore infestation compared with soils with low ( 0 to 19 oospores $\mathrm{g}^{-1}$ soil) infestation. Our study confirms that oospores can survive winter fallow and serve as a source of primary inoculum in the central highlands of Mexico. Oospore survival appeared lower in the Toluca Valley soil, which may be an indication of soil suppressiveness.
\end{abstract}

Additional keywords: bioassay, oomycete, potato late blight

Oospores are sexual, reproductive spores of oomycetes. In the species Phytophthora infestans (Mont.) de Bary, oospores are formed when two isolates of opposite mating type, referred to as A1 and A2, interact. The two mating types of $P$. infestans occur in a 1:1 ratio in the Toluca valley located in the central highlands of Mexico $(12,13,15)$, a situation consistent with a population that is sexually reproducing. The formation of oospores in nature by the potato late blight pathogen $P$. infestans was first described in 1956 in the Toluca Valley (23) and independently confirmed 2 years later (12). Oospores have been observed to form in nature in the Toluca valley on cultivars that are either susceptible or resistant to potato late blight $(12,23,24)$, on potato tu-

Corresponding author: N. J. Grünwald E-mail: ngrunwald@pars.ars.usda.gov

This work was funded by PICTIPAPA (Programa Internacional Cooperativo del Tizón Tardío de la Papa), the CEEM (Cornell-Eastern Europe-Mexico) Potato Late Blight Project, USDA CRIS project 5354-21220-009-00, and the JANE (John and Anne Niederhauser) award given to S. P. Fernández-Pavía.

Accepted for publication 14 August 2003.

Publication no. D-2003-1112-01R

(C) 2004 The American Phytopathological Society bers (8), and on several wild species of Solanum (9).

Circumstantial evidence indicates that oospores can be important in the disease cycle of the potato late blight pathogen by serving as primary inoculum $(1,24)$. Infectivity of soil collected 2 years after a severe late blight epidemic occurred in a potato field in the Toluca valley was tested in the greenhouse (24). Potato plants grown in this soil developed infection on the lower parts of stems and on the leaves close to or in contact with soil, which were attributed to the presence of oospores in the soil. A study performed in Sweden suggested that late blight in one field was initiated from soilborne inoculum, presumably oospores (1). Under controlled conditions, oospores produced in vitro and added in high concentrations to soil caused infection of underground stems and tubers (26), indicating that oospores were infective.

Oospores likely survive for many months because $P$. infestans oospores withstand freezing temperatures under laboratory conditions (7) and overwinter in fields in which the oospores had been inoculated $(4,21,22,25,27,30)$. A study performed in the Netherlands documented oospore survival for up to 48 months in sandy and 34 months in light clay soil (27).
Potato growers in some locations in Mexico, where viable oospores have been detected in soil (S. P. Fernández-Pavía, unpublished), grow potatoes every other year to reduce late blight severity (J. IretaMoreno, personal communication). Although unconfirmed, this practice suggests that soilborne inoculum viability decreases after 1 year, but no studies have been conducted in Mexico to determine if oospore viability and infectivity decreases.

We evaluated several hypotheses concerning soils naturally infested with oospores: (i) that oospores remain infective during the winter fallow, (ii) that oospore viability decreases over time, (iii) that infectivity of oospores is correlated with the number of viable oospores, and (iv) that higher oospore density leads to more primary stem lesions. In order to conduct these studies we first had to develop the methodology to selectively eliminate sporangia from soil samples without affecting oospore viability. We then tested these hypotheses using field soils naturally infested with different concentrations of oospores.

\section{MATERIALS AND METHODS}

Soil characteristics. Soils were sampled from three locations in the central highlands of Mexico. The Toluca valley samples were collected in Metepec (2,640 m above sea level). Samples also came from Huiloapan and Ocozacapa-La Cabaña, located in Santa Catarina del Monte, Municipio of Texcoco $(3,140 \mathrm{~m}$ above sea level). The Toluca valley soil is a sandy clay loam soil with $59.46 \%$ sand, $20.02 \%$ silt, and $20.52 \%$ clay, an organic matter content of $1.98 \%$, and $\mathrm{pH} 5.47$. The Huiloapan soil is a sandy loam soil that contains $55.46 \%$ sand, $30.02 \%$ silt, and $14.52 \%$ clay, an organic matter content of $4.3 \%$, and $\mathrm{pH}$ 6.75. The Ocozacapa-La Cabaña soil contains $43.64 \%$ sand, $38 \%$ silt, and $18.36 \%$ clay and is characterized as a loam soil with an organic matter content of $3.7 \%$ and $\mathrm{pH}$ 6.62. Soil analyses were performed in the laboratory of $\mathrm{Nu}$ trición Vegetal, Colegio de Postgraduados, Mexico. Soil texture was determined by the Bouyoccous method and $\mathrm{pH}$ was measured on a 2:1 soil:water slurry (6).

Soil bioassay. A soil bioassay, adapted from Drenth et al. (4), was used to detect $P$. 
infestans in soil. The soil was thoroughly mixed with water $(4: 1 \mathrm{wt} / \mathrm{vol})$ in a plastic container (18 by $13 \mathrm{~cm}$ ) and maintained at $15^{\circ} \mathrm{C}$ with a 14 -h photoperiod in a growth chamber. After $48 \mathrm{~h}$, eight leaflets of the susceptible potato cv. Alpha were floated upside down as baits. Leaflets were inspected daily for infection, and infections were recorded over a period of 7 to 30 days after initiation of the bioassay. When leaflets began to appear senescent, fresh leaflets were added so that nonsenescent leaflets were exposed to each sample at all times.

To quantify oospore infectivity in soils, the bioassay was conducted with modifications (14). Sterile microtiter plates (24 wells; Evergreen Scientific, CA) were used; $1 \mathrm{~g}$ of dry soil and $1.5 \mathrm{ml}$ of water were added to each well. The soil was stirred and covered by a 9-mm-diameter potato leaf disc. The discs were inspected daily and infected leaf discs were immediately removed to avoid contamination of neighboring wells. Each infected disc was recorded and the experiment was continued until there were at least 30 continuous days in which no newly infected discs were observed. The proportion of wells that led to infected discs and the time required to detect infection were recorded. Three plates were used for each assay and the proportion of leaflets out of 72 calculated for each observation. The assays were repeated four times.

Elimination of sporangia. Several methods were tested for their efficacy in eliminating sporangia from soil samples while preserving viability of oospores. Sporangia were produced from an isolate of $P$. infestans (mating type, A2; Peptidase allozyme pattern, 96/96; Glucose-6-phosphate-isomerase allozyme pattern, 86/100) originally isolated from soil and maintained on leaflets of cv. Alpha at all times. Leaflets were inoculated with a zoospore suspension and kept in a humidity chamber at room temperature $\left(20^{\circ} \mathrm{C} \pm 4\right)$. Sporangia were obtained from sporulating leaflets 5 days after inoculation. A suspension (15 $\mathrm{ml}, 20,000$ sporangia $\mathrm{ml}^{-1}$ ) was added to soil. The following treatments were tested for their ability to eliminate sporangia from soil:

Freezing treatments. Because the literature mentions freezing as a method of eliminating sporangia from soil samples $(5,27)$, we investigated various freezing treatments using soils from Metepec. Some treatments used pasteurized soils (maintained at $65^{\circ} \mathrm{C}$ for 5 days), some treatments used sterilized soils (100-g samples autoclaved at $121^{\circ} \mathrm{C}$ for $60 \mathrm{~min}$ ), and some treatments used untreated soils. Sporangia in suspensions or on leaflets were added to dry and wet soil (100 g of soil wetted with $30 \mathrm{ml}$ of water). Sporangial suspensions consisted of $15 \mathrm{ml}$ of inoculum suspension $\left(20,000\right.$ sporangia $\left.\mathrm{ml}^{-1}\right)$ plus $15 \mathrm{ml}$ of water. Sporulating leaflets were completely covered with soil. Treated soils were maintained in clear plastic bags. Treatments consisted of freezing the soils at $-16 \pm 4^{\circ} \mathrm{C}$ for 0,24 , and $48 \mathrm{~h}$. Following the freezing treatments, a soil bioassay was performed. Each treatment was replicated twice and all experiments were repeated four times.

Drying treatments. Drying treatments were conducted on sporangia in pasteurized and sterilized field soil. Soil was moistened with $15 \mathrm{ml}$ of water per $100 \mathrm{~g}$ of soil prior to addition of sporangia in a suspension ( $15 \mathrm{ml}$ of 20,000 sporangia $\mathrm{ml}^{-1}$ ). Soil water content was approximately $30 \%$ prior to any drying treatment. Soil samples containing sporangia were dried by placing them in Buchner funnels and maintaining them at $22^{\circ} \mathrm{C}$ for 5 days. In another treatment, dried soils were further subjected to a second drying cycle by adding $30 \mathrm{ml}$ of water to the soil, then dried as before. Soil gravimetric water content was determined on all soil samples. A subsample of soil was weighed to obtain fresh weight while another subsample of soil was dried in two replicates $\left(105^{\circ} \mathrm{C}\right)$ until weight remained constant (about $18 \mathrm{~h}$ ). Gravimetric soil water content after two drying cycles ranged from 3 to $7 \%$. Viability of sporangia was tested after one or two drying cycles using the soil bioassay as described above. Each treatment was replicated twice and each experiment was repeated four times.

Effect of treatments on oospores. We tested whether oospore viability might be negatively affected by treatments to eliminate sporangia. We tested soils from Huiloapan, Mexico that were naturally infested with oospores and which had been shown previously to be highly infective in the bioassay. These soils contained an average of 61 oospores $\mathrm{g}^{-1}$ of soil. We determined the percentage of oospores that were viable (using the plasmolysis test, described below) before and after different treatments in four independent extractions. Means were compared with a $t$ test for two independent samples.

A soil bioassay was conducted on the Huiloapan soil to determine infectivity before and after two drying cycles. As a control treatment, $15 \mathrm{ml}$ of a sporangial suspension $\left(20,000\right.$ sporangia $\left.\mathrm{ml}^{-1}\right)$ was added to pasteurized Huiloapan soil and tested before and after two drying cycles. Infectivity of pasteurized field soil was tested previously and no infection was observed.

Oospore extraction and quantification. Oospores were extracted from soil using the method described by Van der Gaag and Frinking (28) adapted as described below. Soil (10 g) was wetted with $100 \mathrm{ml}$ of water and thoroughly mixed by hand. The suspension was filtered through a $100-\mu \mathrm{m}$ sieve and a $15-\mu \mathrm{m}$ nylon mesh (Tekto Inc., Kansas City, MO). The residue on the $15-\mu \mathrm{m}$ nylon mesh was washed with $20 \mathrm{ml}$ of water into a tube and $30 \mathrm{ml}$ of a
$70 \%$ sucrose solution was added to the suspension. The suspension was centrifuged for $5 \mathrm{~min}$ at 3,500 rpm, and the resulting supernatant was filtered through the $15-\mu \mathrm{m}$ nylon mesh and retrieved into $15 \mathrm{ml}$ of water. The suspension was centrifuged for $10 \mathrm{~min}$ at $3,500 \mathrm{rpm}$ and the supernatant pipetted off until $1 \mathrm{ml}$ remained. Oospores were counted in five $20-\mu \mathrm{l}$ aliquots under the microscope at $\times 10$ magnification. The entire $20 \mu \mathrm{l}$ were inspected. The oospore concentration was calculated as the total number of oospores per gram of soil based on an average of the five samples counted. A soil was considered to have a low, moderate, or high oospore concentration if it contained 0 to 19,20 to 39 , or $>39$ oospores $\mathrm{g}^{-1}$ soil, respectively. Ornamented oospores and oospores that were either too big or too small compared with those commonly observed for $P$. infestans under controlled conditions in detached leaflets were not counted.

Oospore viability. The number of viable oospores in soil samples was determined using the plasmolysis test described by Jiang and Erwin (18) with some minor modifications. Oospores were extracted from soil as described above and kept overnight in a $2 \mathrm{M} \mathrm{NaCl}$ solution. Plasmolyzed and nonplasmolyzed oospores were counted for each soil sample in five subsamples of $20-\mu \mathrm{l}$ each using a compound microscope at $\times 10$ magnification.

Field experiment. A field experiment was initiated in 1998 to measure survival of naturally produced oospores under Toluca Valley conditions and to relate oospore numbers to initial field infections. In a portion of the field in which potato plants had been absent for the previous 6 years, we planted an area $(10$ by $40 \mathrm{~m})$ to the susceptible cv. Alpha in June 1998, using grower practices typical for the Toluca valley (16). To assure oospore production in the potato leaf tissue, we slowed the rate of epidemic development with weekly applications of chlorothalonil (at 25\% of the commercial rate of $0.29 \mathrm{~kg}$ a.i. $\mathrm{ha}^{-1}$ ). The soil supporting plants with this slow epidemic subsequently was regarded as "moderately infested" with oospores. Adjacent to the moderately infested area was a 10-by-40-m area that had not been planted with potato for at least 6 years and was left fallow for the 1998 cropping season. This area is subsequently regarded as "lightly infested" with oospores.

The lightly infested and moderately infested areas were used in 1999 and 2000 to test whether a moderate infestation of oospores in soil could infect potato plants in the field. A total of four plots were planted in each of the lightly or moderately infested areas. Cv. Alpha was planted on 30 June 1999 and 14 July 2000 in 3-by-3-m plots. The number of infected stems at the soil interface was counted daily and the date when new lesions appeared was recorded up to 5.5 weeks after planting. 
Thereafter, many stem lesions might have originated from aerial inoculum through splash dispersal from neighboring infected stems or from soilborne inoculum. Disease severity (\%) was estimated visually as described previously (11) on a plot basis 5 to 7 weeks after planting. The concentrations of oospores in soils with moderate infestation and with light infestation were determined with the oospore-extraction method described above on 10 samples taken in each area.

Oospore infection under greenhouse conditions. To assess whether oospores can lead to infection of stems under controlled conditions, a greenhouse study was conducted using naturally infested soil from Huiloapan. Four minitubers of cv. Alpha were planted in the greenhouse in clay pots using dried Huiloapan soil. Four tubers were planted in pasteurized soil as a control. Soil was kept wet at all times (approximately $66 \%$ soil water content). Greenhouse temperatures remained in a range of $22 \pm 3^{\circ} \mathrm{C}$. Plants were inspected for stem lesions up to 60 days after planting. When stem lesions were observed, infected tissue was removed to a moist chamber to induce sporulation. The experiment was conducted twice.

Oospore infectivity during winter fallow. Soil samples from potato fields in the Toluca Valley, Huiloapan and from Ocozacapa-La Cabaña were collected during the winter fallow. The soils contained low, moderate (Toluca valley), or high (Huiloapan and Ocozacapa-La Cabaña) oospore concentrations. Soils were collected during the months of November (1999 and 2000), January (2000 and 2001), March (2001), and June (2000 and 2001) in the Toluca valley. In Huiloapan, soils were sampled during October 1999 and July 2001, 3 months after harvest and after 2 years of winter fallow, respectively. In Ocozacapa-La Cabaña, soil was sampled 3 months after harvest. Ten soil samples taken from the upper $15 \mathrm{~cm}$ were bulked from each period and location. Infectivity was determined with the soil bioassay described above after sporangia were eliminated by subjecting soil samples to two drying cycles. A $t$ test for two independent samples was conducted to determine if differences in viability and infectivity were observed over time with Huiloapan soil.

\section{RESULTS}

Elimination of sporangia from soil. Several methods were evaluated for their ability to selectively eliminate sporangia from soil samples while minimizing harmful effects on oospores. Sporangia added in water suspensions or on sporulating leaflets were not eliminated by the freezing treatments because infection was observed in all bioassays within 5 to 7 days. Similarly, one drying cycle was not effective in eliminating sporangia from soil (Table 1).
However, successful elimination of sporangia was obtained using two drying cycles (Table 1). Oospore viability was not significantly affected by this treatment $(P$ $=0.05)$. The average percentage of oospores that were viable in the Huiloapan soil before and after two drying cycles were 35.8 and $25.7 \%$, respectively. Oospores from naturally infested soils in Huiloapan remained infective after two drying cycles. Oospores were successfully eliminated by pasteurizing the soil, because no sporulating leaflets were observed in the bioassay following pasteurization (Table 2). Thus, two cycles of soil drying were considered the method of choice for selective elimination of sporangia from soil without eliminating oospore viability.

Oospores remain infective during winter fallow. $P$. infestans oospores in naturally infested soils remained infective throughout the winter fallow in soils with moderate and high infestation. Oospores survived 2 years without a potato crop in two different soil types (Huiloapan and Toluca valley) from the central highlands of Mexico (Table 3). However, the viability of oospores in the Huiloapan soil decreased significantly $(P<0.05)$ after 24 months (Table 4). Infectivity was not detected during the winter fallow in the

Table 1. Number of leaflets infected in different treatments for elimination of sporangia of Phytophthora infestans from soil samples

\begin{tabular}{lc}
\hline Treatment $^{\mathbf{a}}$ & Leaflets infected $^{\mathbf{b}}$ \\
\hline Sporangia suspension/dry soil, one drying cycle & $6 / 8$ \\
Sporangia suspension/dry soil, two drying cycles & $0 / 8$ \\
Sporangia suspension/wet soil, no drying cycle & $8 / 8$ \\
\hline a Sporangium viability was assessed using a bioassay, where the occurrence of infected leaflets indi- \\
cated viable sporangia. Sporangia were added to wet and to dry soil as a sporulating lesion on a \\
leaflet or in a water suspension. All experiments were repeated four times with two replicates per \\
experiment. The results shown are from a single experiment and are representative of all experi- \\
ments conducted. \\
b Shown are the number of leaflets infected after a 7-day period out of the total number of leaflets \\
exposed in the bioassay.
\end{tabular}

Table 2. Infectivity of a naturally infested soil from Huiloapan, Mexico

\begin{tabular}{lc}
\hline Treatment & Infected leaflets $^{\mathbf{a}}$ \\
\hline Field soil (wet soil) & $8 / 8$ \\
Field soil, two drying cycles & $8 / 8$ \\
Pasteurized field soil & $0 / 8$ \\
Pasteurized field soil + sporangia (wet soil) & $8 / 8$ \\
Pasteurized field soil + sporangia, two drying cycles & $0 / 8$ \\
\hline
\end{tabular}

a Sporangium viability was assessed using a bioassay, where the occurrence of infected leaflets indicated presence of viable sporangia or oospores. Shown are averages of the number of leaflets infected in a bioassay from two independent experiments with two replicates per experiment.

Table 3. Bioassay for infectivity of oospores in naturally infested soils from central Mexico ${ }^{\mathrm{a}}$

\begin{tabular}{lcc}
\hline Oospore infestation, date $^{\mathbf{b}}$ & Infection & Infection observed (days) \\
\hline Low infestation (Toluca) & - & - \\
November 1999 & - & - \\
January 2000 & - & - \\
June 2000 & - & - \\
November 2000 & - & - \\
January 2001 & - & - \\
March 2001 & - & - \\
June 2001 & & $5-9$ \\
Moderate infestation (Toluca) & + & $11-21$ \\
November 1999 & + & $10-21$ \\
January 2000 & + & $8-10$ \\
June 2000 & + & $10-16$ \\
November 2000 & + & $13-29$ \\
January 2001 & + & $10-16$ \\
March 2001 & + & $9-25$ \\
June 2001 & & $8-17$ \\
High infestation (Huiloapan) & + & $9-15$ \\
October 1999 & + & \\
High 2001 infestation (Ocazacapa-La Cabaña) & + & \\
October 1999 & + & \\
\hline
\end{tabular}

${ }^{a}$ All soils had been subjected to two drying cycles to eliminate sporangia; $+=$ infection observed and $-=$ infection not observed.

${ }^{\mathrm{b}}$ Low $=0$ to 19 , moderate $=20$ to 39 , and high $>39$ oospores $\mathrm{g}^{-1}$ soil. 
Toluca soil with low infestation (Table 3). The timing at which detection of infections via the bioassay occurred was diverse from experiment to experiment using the same

soil, a result consistent with asynchronous germination of oospores.

Oospore infectivity in the field and greenhouse. Soils moderately infested

Table 4. Oospore concentration, viability, and infectivity in a naturally infested soil from Huiloapan assayed 3 and 24 months after the cropping period $(1999)^{\mathrm{a}}$

\begin{tabular}{|c|c|c|c|}
\hline Year & Oospores $\mathrm{g}^{-1}$ soil $($ mean $\pm \mathrm{SD})$ & Viable oospores $\mathrm{g}^{-1}$ soil $(\%)$ & Infected leaf discs (\%) \\
\hline 1999 & $61 \pm 51$ & 35.7 & $32 \pm 30$ \\
\hline 2001 & $55 \pm 7.2$ & 16.7 & $2.5 \pm 20$ \\
\hline
\end{tabular}

a Data shown are means \pm standard deviations from three independent extractions and three experiments with three replications, respectively.
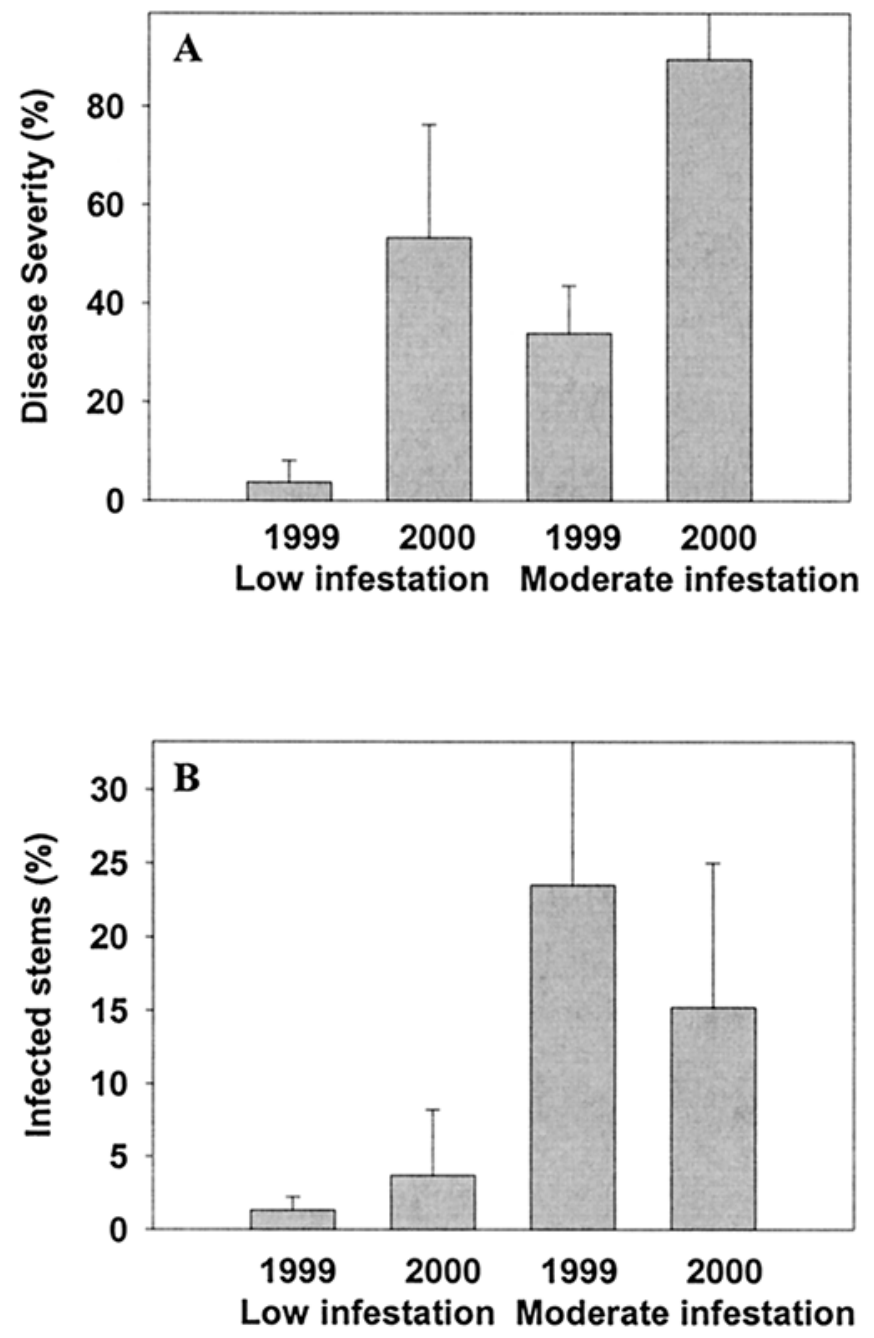

Fig. 1. Effect of oospore concentration on $\mathbf{A}$, disease severity and $\mathbf{B}$, number of primary stem lesions at the soil interface in soils with low or moderate oospore infestation, during 1999 and 2000, in four replicate plots. Shown are means \pm standard deviations.

Table 5. Oospore concentration, viability, and infectivity in three soils sampled in central Mexico 3 months after harvest ${ }^{\mathrm{a}}$

\begin{tabular}{lccc}
\hline Soil $^{\mathbf{b}}$ & $\begin{array}{c}\text { Oospores } \mathbf{g}^{\mathbf{- 1}} \text { soil } \\
(\mathbf{m e a n} \pm \mathbf{S D})\end{array}$ & $\begin{array}{c}\text { Viable oospores } \mathbf{g}^{\mathbf{- 1}} \\
\text { soil }(\boldsymbol{\%})\end{array}$ & $\begin{array}{c}\text { Infected leaf discs } \\
(\boldsymbol{\%})\end{array}$ \\
\hline Toluca (low) & $11 \pm 4.8$ & 1 & 0 \\
Toluca (moderate) & $23 \pm 11.2$ & 21 & 0 \\
Huiloapan (high) & $61 \pm 51$ & 35.7 & $31.7 \pm 30$ \\
Ocozacapa-La Cabaña (high) & $88 \pm 54$ & 60 & $71.3 \pm 16$ \\
\hline
\end{tabular}

a Shown are means \pm standard deviations from three independent extractions and four bioassays with three replicates each.

${ }^{\mathrm{b}}$ Low $=0$ to 19 , moderate $=20$ to 39 , and high $>39$ oospores $\mathrm{g}^{-1}$ soil. with oospores resulted in significantly higher numbers of primary stem lesions at the soil interface and significantly higher disease severity than on plants in soils with low infestation $(P<0.05)$ during the 1999 and 2000 field experiments (Fig. 1A and B). In the field experiments, stem lesions appeared 24 days after planting in 1999 and 38 days after planting in 2000. Under greenhouse conditions, the first stem lesion appeared 39 and 50 days after planting in the first and second experiments, respectively.

Infectivity and oospore concentration are positively correlated. The infectivity of the three soils from central Mexico was positively correlated with both oospore concentration and viability (Table 5). The bioassay in microtiter plates detected no infections from oospores in soils from Toluca with low and moderate oospore infestations.

\section{DISCUSSION}

Our data are consistent with the expectation that oospores serve as a source of primary inoculum in the central highlands of Mexico. Stem lesions at the soil interface and subsequent disease severity were significantly higher on plants grown in a soil with moderate oospore infestations than in a soil with a light infestation. The bioassay detected more infections from soils with high oospore concentrations than from soils with low oospore concentrations.

Differences in oospore numbers were detected in soils from different locations. The lowest oospore infestation was detected in Metepec (Toluca Valley). Our results confirm a previous report that soils collected in the Toluca Valley show low oospore infestation in the upper $10 \mathrm{~cm}$ of soil (2). The reason for low infestations is not immediately apparent because oospores have been shown to be produced on naturally infected leaflets (12). Factors that might reduce oospore survival in Toluca soils remain undefined.

Soilborne oospores survived winter fallow in the central highlands of Mexico and were capable of initiating infections. Under greenhouse conditions, naturally infested soils from Huiloapan caused lesions on the lower stems of potato plants. Others also have reported that naturally occurring soilborne inoculum causes infection $(1,4,24)$. Our study confirms that oospores can survive in soil and can initiate epidemics.

Oospore viability and infectivity in soil decreased with time after a potato crop; however, even 2 years after a crop, we could detect viable oospores. Nonetheless, crop rotation used by many potato growers in Mexico probably helps suppress late blight.

Oospores do not appear to germinate synchronously. Under our experimental conditions, visible symptoms of infection were detected on floating leaflets between 
5 and 29 days after initiation of the assay using the same soil sample. Similar results have been reported for artificially inoculated soils in the Netherlands (27). Asynchronous germination of oospores, as reported for other Phytophthora spp. $(10,17,19,20)$, also could explain why the detection of the first stem lesions ranged from 24 to 38 days after planting in field trials. Likewise, first detections of lower stem lesions ranged from 39 to 50 days on plants grown in the greenhouse in soils that presumably had oospores (24). Oospores may remain dormant for different lengths of time and thus maintain a low but continuously infective population (29).

Sporangia commonly are found in soil samples along with oospores. Freezing soil samples with sporangia or using only one drying cycle did not eliminate sporangia from soil samples. Unlike De Bruyn's (3) findings, which show that $P$. infestans withstands low temperatures under dry conditions better than in moist conditions, we found no difference between dry and wet soil at freezing temperatures (data not shown). A treatment of two drying cycles was the best method by which to selectively eliminate sporangia from soil samples without significantly reducing oospore viability. Dryness is considered one of the greatest hazards to survival of Phytophthora mycelium, sporangia, and zoospores $(5,29)$.

Our study confirms that oospores survive winter fallow and contribute significantly to the initiation of potato late blight epidemics in the central highlands of Mexico. We found that some soils supported larger concentrations of oospores than other soils, but the explanation for this phenomenon awaits further investigation. The presence of oospores in soil is a recent phenomenon in many potato-growing areas of the world, such that methods of reducing oospore numbers in soil probably need to be considered. Crop rotation is immediately available as a management tool, and enhancement of soil suppressiveness might become a reality.

\section{ACKNOWLEDGMENTS}

We thank W. Flier for helping with the planting of the field plots, and A. Sturbaum and $\mathrm{H}$. Mayton for their suggestions to improve the manuscript.

\section{LITERATURE CITED}

1. Andersson, B., Sandstrom, M., and Stromberg, A. 1998. Indications of soil borne inoculum of Phytophthora infestans. Potato Res. 41:305-310.

2. Cuervo, U. M. Y. 1979. Relaciones de los suelos derivados de cenizas volcánicas y andosoles con Phytophthora infestans (Mont.) de Bary y cultivo de papa. B.Sc. thesis, Universidad Nacional Autónoma de México.

3. De Bruyn, H. L. G. 1926. The overwintering of Phytophthora infestans (Mont.) de By. Phytopathology 16:121-139.

4. Drenth, A., Janssen, E. M., and Govers, F. 1995. Formation and survival of oospores of Phytophthora infestans under natural conditions. Plant Pathol. 44:86-94.

5. Erwin, D. C., and Ribeiro, O. K. 1996. Phytophthora Diseases Worldwide. American Phytopathological Society, St. Paul, MN.

6. Etchevers, B. J., Goijberg E. G., López, R. R., Padilla,. C. J., Alvarado, L. J., and Hidalgo, M. C. 2000. Manual de Procedimientos Analíticos para análisis de suelos y plantas del laboratorio de Fertilidad de Suelos, IRENAT-Colegio de Posgraduados, Montecillo, Mexico.

7. Fay, J. C., and Fry, W. E. 1997. Effects of cold and hot temperatures on the survival of oospores produced by United States strains of Phytophthora infestans. Am. Pot. J. 74:315-323.

8. Fernández- Pavía, S. P., Grünwald, N. J., and Fry, W. E. 2002. Formation of Phytophthora infestans oospores in nature on tubers in central Mexico. Plant Dis. 86:73.

9. Flier, W. G., Grünwald N. J., Fry W. E., and Turkensteen, L. J. 2001. Formation, production and viability of oospores of Phytophthora infestans from potato and Solanum demissum in the Toluca Valley, Central Mexico. Mycol. Res. 105:998-1006.

10. Förster, H., Ribeiro, O. K., and Erwin, D. C. 1983. Factors affecting oospore germination of Phytophthora megasperma f. sp. medicaginis. Phytopathology 73:442-448.

11. Fry, W. E. 1977. Integrated control of potato late blight effects of polygenic resistance and techniques of timing fungicide applications. Phytopathology 67:415-420.

12. Gallegly, M. E., and Galindo, J. 1958. Mating types and oospores of Phytophthora infestans in nature in Mexico. Phytopathology 48:274-277.

13. Goodwin, S. B., Spielman, L. J., Matuszak, J. M., Bergeron, S. N., and Fry, W. E.1992. Clonal diversity and genetic differentiation of Phytophthora infestans populations in northern and central Mexico. Phytopathology 82:955-961.

14. Grünwald, N. J. 1997. Characterization of soil nutrient and microbial variables associated with Pythium aphanidermatum and Rhizoctonia solani growth and tomato damping-off during short-term cover crop decomposition. Ph.D. dissertation, University of California, Davis.

15. Grünwald, N. J., Flier, W. G., Sturbaum, A. K., Garay-Serrano, E., van den Bosch, T. B. M., Smart, C. D., Matuszak, J. M., Lozoya-
Saldaña, H., Turkensteen, L. J., and Fry, W. E. 2001. Population structure of Phytophthora infestans in the Toluca Valley region of central Mexico. Phytopathology 91:882-890.

16. Grünwald, N. J., Rubio-Covarrubias, O. A., and Fry, W. E. 2000. Potato late-blight management in the Toluca valley: forecast and resistant cultivars. Plant Dis. 84:410-416.

17. Hord, M. J., and Ristaino, J. B. 1991. Effects of physical and chemical factors on the germination of oospores of Phytophthora capsici in vitro. Phytopathology 81:1541-1546.

18. Jiang, J., and Erwin, D.C. 1990. Morphology, plasmolysis and tetrazolium bromide stain as criteria for determining viability of $P h y$ tophthora oospores. Mycologia 82:107-113.

19. Jimenez, B., and Lockwood, J. L. 1982. Germination of oospores of Phytophthora megasperma f. sp. glycinea in the presence of soil. Phytopathology 72:662-666.

20. Lucas, J. A., Greer, G., Oudemans, P. V., and Coffey, M. D. 1990. Fungicide sensitivity in somatic hybrids of Phytophthora capsici obtained by protoplast fusion. Physiol. Mol. Plant Pathol. 36:175-187.

21. Mayton, H., Smart, C. D., Moravec, B. C., Mizubuti, E. S., Muldoon, A. E., and Fry, W. E. 2000. Oospore survival and pathogenicity of single oospore recombinant progeny from a cross involving US-17 and US-8 genotypes of Phytophthora infestans. Plant Dis. 84:1190-1196.

22. Medina, M. V., and Platt, H. W. 1999. Viability of oospores of Phytophthora infestans under field conditions in Northeastern North America. Can. J. Plant Pathol. 21:137-143.

23. Niederhauser, J. S. 1956. The blight, the blighter and the blighted. Trans. N. Y. Acad. Sci. 19:55-63.

24. Perches, S., and Galindo, A. J. 1969 Supervivencia del Phytophthora infestans (Mont.) de Bary, causante del tizón tardío de la papa y jitomate. Agrociencia 5:92-98.

25. Pittis, J. E., and Shattock, R. C. 1994. Viability, germination and infection potential of oospores of Phytophthora infestans. Plant Pathol. 43:387-396.

26. Stromberg, A., Persson, L., and Wikstrom, M. 1999. Infection of potatoes by oospores of Phytophthora infestans in soil. Plant Dis. 83:876.

27. Turkensteen, L. J., Flier, W. G., Wanningen, R., and Mulder, A. 2000. Production, survival and infectivity of oospores of Phytophthora infestans. Plant Pathol. 49:688-696.

28. Van der Gaag, D. J., and Frinking, H. D. 1997. Extraction of oospores of Peronospora viciae from soil. Plant Pathol. 46:675-679.

29. Weste, G. 1983. Population dynamics and survival of Phytophthora. Pages 237-257 in: Phytophthora: Its Biology, Taxonomy, Ecology and Pathology. D. C. Erwin, S. BartnickiGarcia, and P. H. Tsao, eds. American Phytopathological Society, St. Paul, MN.

30. Zarzycka, H., and Sobkowiak, S. 1997. Formation and survival of oospores and their role as primary infection source of the pathogen. Plant Breed. Seed Sci. 41:27-38. 